\title{
Results from Ethiopia's 2018 Report Card on Physical Activity for Children and Youth
}

\author{
Chalchisa Abdeta, Zelalem Teklemariam, Alem Deksisa, \\ and Endashew Abera
}

\section{Introduction}

Physical activity is crucial for all ages including children and youth. For children, types of physical activity include active play, walking or biking, exercising, recreational activities, school based activities, etc. Children and youth aged from 5-17 years old are advised to participate in at least 60 minutes of moderate to vigorous intensity aerobic activities daily. Not fitting this guideline is considered children and youths are physically inactive. ${ }^{1-4}$ Data are limited on physical activity for children and youth in Ethiopia. Thus, this paper aimed to summarize the results of the Ethiopia's 2018 Report Card on physical activity for children and youth. The report card was graded based on the latest available evidence.

\section{Methods}

Initially, the country report card team members were identified based on their expertise on physical activity. Team members collected data from December 2017 to April 2018. Children and youth aged from 5-17 years were included in the report card. Data were collected and searched on respective government sectors websites, Google scholar and World Health Organization (WHO) HINARI database. The 10 core indicators (Overall Physical Activity, Organized Sport and Physical Activity, Active Play, Active Transportation, Sedentary Behaviors, Physical Fitness, Family and Peers, School, Community and Environment, and Government), study populations' age group and country name were used as keywords for searching strategies. A review of literatures, policy documents and experts interview were made following Active Healthy Kids Global Alliance (AHKGA) guidance. The country Sport policy document was used in the report card development. ${ }^{5}$ Where data for an indicator was unavailable, a grade was assigned using phone-based interviews with a panel of experts. Then, average estimation was taken to grade the report card.

\section{Results and Discussion}

Even though evidence was limited, major efforts were made to develop Ethiopia's first Report Card on Physical Activity for Children and Youth (see Figure 1). The grade for each indicator and its rationale are shown on Table 1. Only the physical fitness indicator received an incomplete grade. This is due to difficulty to get or estimate the fitness data in the country. All other indicators were graded using available data and/or expert estimation. Active play indicator scored the highest grade among the 10 core indicators.

Our result showed that there is low physical activity participation among children and youth in Ethiopia. Our findings aligned with different evidences that revealed the pandemic of physical inactivity across the world. ${ }^{6}$ Evidence showed that childhood obesity and physical inactivity are on rapid rise that push children and youth for greater risk of non-communicable diseases later in life. This is mainly due to unhealthy diet, physical inactivity and sedentary behaviour. The screen-based technologies such as smartphone, computer, play games, Television and others are discouraging children \& youth to move. ${ }^{7,8}$ Thus, major tasks are expected from researchers, families, governments, non-governmental organizations (NGOs), civil societies and private sectors to increase children and youth's physical activity levels. Since this report card was assessed subjectively some limitations can be recognized.

\section{Conclusion}

This paper revealed evidence of policy and practice gaps regarding physical activity for children and youth. Thus, it is suggested that investigators prioritize physical activity research, policy and practice for children and youth in Ethiopia.

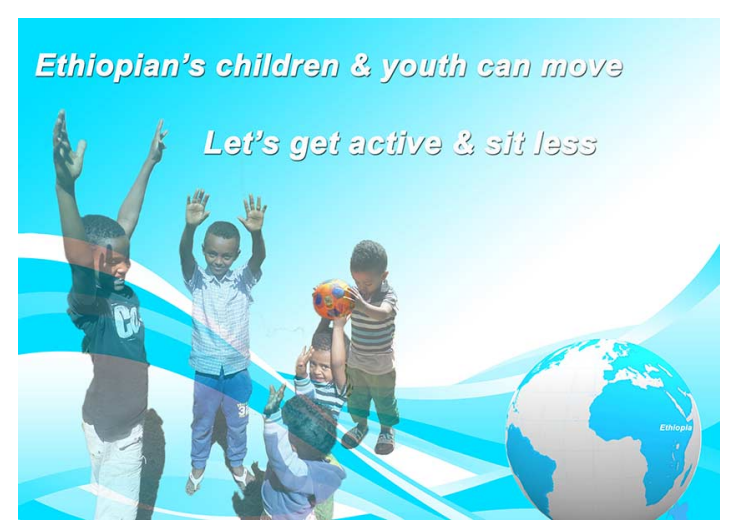

Figure 1 - Ethiopia's 2018 Report Card Cover.

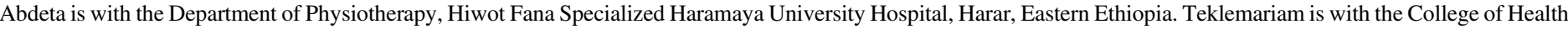

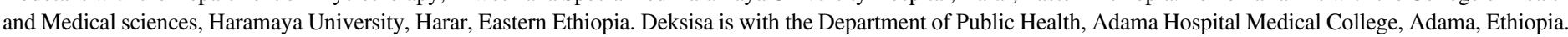
Abera is with the Clubfoot Program, Cure Ethiopia Children Hospital, Addis Ababa, Ethiopia. Abdeta (caaliphysio@gmail.com) is corresponding author. 
Table 1 Grades and rationales for Ethiopia's 2018 Report Card

\begin{tabular}{|c|c|c|}
\hline Indicator & Grade & Rationale \\
\hline $\begin{array}{l}\text { Overall Physical } \\
\text { Activity }\end{array}$ & $\mathrm{D}$ & $\begin{array}{l}\text { Majority of Ethiopian children and youth take part in home chores and light work every day for family help. Our team } \\
\text { estimated that about } 28 \% \text { of children and youth ( } 17 \% \text { urban \& } 39 \% \text { rural) meet } 60 \text { minutes moderate physical activity } \\
\text { every day. }\end{array}$ \\
\hline $\begin{array}{l}\text { Organized Sport } \\
\text { Participation }\end{array}$ & $\mathrm{C}$ & $\begin{array}{l}\text { Almost } 50 \% \text { of children and youth are participating in school athletics, handball, volleyball and football } \\
\text { competitions at all levels for several times in a year. }\end{array}$ \\
\hline Active Play & B & $\begin{array}{l}\text { Experts estimated that } 71 \% \text { of children and youth involved in active play for a minimum of } 2 \text { hours a day before, } \\
\text { during and after school. }\end{array}$ \\
\hline Active Transportation & $\mathrm{C}$ & Approximately $48 \%$ of children and youth ( $31 \%$ in urban and $65 \%$ rural) are walking to and from school. \\
\hline Sedentary Behaviours & $\mathrm{F}$ & $\begin{array}{l}\text { About } 13 \% \text { of children and youth spend on screen time such as mobile game, play station and TV views for no more } \\
\text { than } 2 \text { hours per day. }\end{array}$ \\
\hline Physical Fitness & INC & There is no adequate information in the country to assign a grade for this indicator. \\
\hline Family and Peers & $\mathrm{F}$ & $\begin{array}{l}\text { Approximately } 14 \% \text { of children and youth are encouraged and get support from their family members like buying } \\
\text { bike, handball or football for their child to move. }\end{array}$ \\
\hline School & $\mathrm{D}$ & $\begin{array}{l}\text { Our team estimated that } 32 \% \text { of schools in the country have access of infrastructures like sport field, outdoor } \\
\text { playground, multi-purpose spaces for physical activity. }\end{array}$ \\
\hline $\begin{array}{l}\text { Community and } \\
\text { Environment }\end{array}$ & $\mathrm{F}$ & $\begin{array}{l}\text { Approximately } 8 \% \text { of children and youth live in environment that have inevitable infrastructure like sidewalks to } \\
\text { engage in physical activity. }\end{array}$ \\
\hline Government & $\mathrm{D}$ & $\begin{array}{l}\text { Policy exists regarding physical activity in the country's non-communicable diseases (NCDs) agenda. However, it is } \\
\text { not implemented yet. }\end{array}$ \\
\hline
\end{tabular}

\section{References}

1. WHO. Global Recommendations on Physical Activity for Health. Geneva, Switzerland: World Health Organization; 2011. doi:10. 1080/11026480410034349

2. Carson V, Chaput JP, Janssen I, Tremblay MS. Health associations with meeting new 24-hour movement guidelines for Canadian children and youth. Prev Med (Baltim). 2017;95:7-13. doi:10.1016/j. ypmed.2016.12.005

3. WHO. Physical Activity Fact Sheet. Geneva, Switzerland: World Health Organization; 2017. http://www.who.int/mediacentre/ factsheets/fs385/en/. Accessed June 18, 2018.

4. WHO. Global Action Plan on Physical Activity 2018-2030: More Active People for a Healthier world. Geneva, Switzerland: World Health Organization; 2018.
5. MOYS. Sport Policy of the Federal Democratic Republic of Ethiopia. Addis Ababa, Ethiopia; Ministry of Youth and Sport; 1998.

6. Kohl HW, Criag CL, Lambert EV, et al. The pandemic of physical inactivity: global action for public health. Lancet. 2012;380(9838): 294-305.

7. CSSP. Results-Based Public Policy Strategies for Preventing Childhood Obesity. The Center for the Study of Social Policy; 2011. www. POLICYforRESULTS.org.

8. Win AM, Yen LW, Tan KHX, Lim RBT, Chia KS, MuellerRiemenschneider F. Patterns of physical activity and sedentary behavior in a representative sample of a multi-ethnic South-East Asian population: A cross-sectional study. BMC Public Health. 2015; $15: 318$. 